\title{
Uji Efektivitas Antibakteri Ekstrak Rimpang Kunyit (Curcuma domestica Val.) terhadap Pertumbuhan Propionibacterium acnes In Vitro
}

\section{Antibacterial Effectiveness Test of Turmeric Rhizome Extract (Curcuma domestica Val.) on the Growth of Propionibacterium acnes in Vitro}

\author{
Annisa Cahyani ${ }^{1}$, Dwi Indria Anggraini ${ }^{2}$, Tri Umiana Soleha ${ }^{3}$, Agustyas Tjiptaningrum ${ }^{4}$ \\ Fakultas Kedokteran, Universitas Lampung, Indonesia
}

\section{ARTICLE INFO}

\section{Article history}

Received date

28 Sept 2020

Revised date

14 Oct 2020

29 Oct 2020

Accepted date

26 Nov 2020

Keywords:

Acne vulgaris;

Propionibacterium acnes;

Thurmeric rhizome.

\section{Kata kunci:}

Akne vulgaris;

Propionibacterium acne;

Rimpang kunyit.

\author{
ABSTRACT/ ABSTRAK
}

One of the treatments for acne vulgaris therapy is antibiotics, it can be applied topically and systemically. However, long-term and inappropriate use of antibiotics can increase the incidence of antibiotic drug resistance. Some medicinal plants are known to have antimicrobial properties, one of them is turmeric rhizome. Turmeric rhizome is known to contain essential oils and curcumin so that it can be useful as an antibacterial, antiviral, anti protozoa, anti-inflammatory, antioxidant, and antineoplasm. This study aims to determine the effectiveness of the antibacterial turmeric extract against the growth of Propionibacterium acnes. The type of this research is an experimental laboratory with disc diffusion method on Mueller Hinton Agar media. Turmeric extract was obtained from the Laboratory of Organic Chemistry at the University of Lampung with maceration techniques using $96 \%$ ethanol. Turmeric rhizome extract is divided into several concentrations namely $15 \%, 30 \%, 50 \%, 75 \%$, and $100 \%$. As negative control is aquades and positive control is clindamycin. Data was obtained based on the result of measurement Diameter of inhibition zone made through paper discs and measured by calipers. The data were analyzed by using One Way ANOVA. The result of this study indicated that the diameter of the inhibits zone at a concentration of $15 \%, 30 \%, 50 \%$, $75 \%$, and $100 \%$. Sequentially is $11,35 \mathrm{~mm}, 15,65 \mathrm{~mm}, 17,575 \mathrm{~mm}, 18,85 \mathrm{~mm}$, and $20,8 \mathrm{~mm}$. in the negative control is $0 \mathrm{~mm}$ and positive control is $28,1 \mathrm{~mm}$ (score $\mathrm{p}$-value $=0,000$ ). There is antibacterial effectiveness of turmeric extract against the growth of Propionibacterium acnes in vitro, but it is no superior compared with clindamycin phosphate.

\begin{abstract}
Salah satu pengobatan untuk terapi akne vulgaris ialah antibiotik, baik secara topikal maupun sistemik. Namun penggunaan antibiotik dalam jangka panjang dan tidak tepat dapat meningkatkan angka kejadian resistensi obat antibiotik. Beberapa tanaman obat diketahui memiliki khasiat sebagai antimikroba, salah satunya ialah rimpang kunyit. Rimpang kunyit diketahui memiliki kandungan minyak atsiri dan kurkumin sehingga dapat bermanfaat sebagai antibakteri, antivirus, antiprotozoa, antiinflamasi, antioksidan dan antineoplasma. Penelitian ini bertujuan untuk mengetahui efektivitas antibakteri ekstrak rimpang kunyit terhadap pertumbuhan Propionibacterium acnes. Jenis penelitian ini adalah eksperimental laboratorium dengan metode disc diffusion pada media Mueller Hinton Agar. Ekstrak rimpang kunyit didapatkan dari Laboratorium Kimia Organik Universitas Lampung dengan teknik maserasi mengunakan etanol 96\%. Ekstrak rimpang kunyit dibagi dalam beberapa konsentrasi yaitu 15\%, 30\%, 50\%, 75\% dan 100\%. Sebagai kontrol negatif adalah akuades dan kontrol positif adalah klindamisin. Data yang diperoleh diukur dengan jangka sorong. Analisis data menggunakan One Way ANOVA. Hasil penelitian ini menunjukkan diameter zona hambat yang terbentuk pada konsentrasi ekstrak rimpang kunyit $15 \%, 30 \%, 50 \%, 75 \%$ dan $100 \%$. Secara berurutan yaitu $11,35 \mathrm{~mm}, 15,65 \mathrm{~mm}, 17,575 \mathrm{~mm}, 18,85 \mathrm{~mm}$, dan 20,8mm. Pada kelompok kontrol negatif sebesar $0 \mathrm{~mm}$ dan kontrol positif sebesar $28,1 \mathrm{~mm}$ (nilai $p$-value=0,000). Terdapat efektivitas antibakteri ekstrak rimpang kunyit terhadap pertumbuhan Propionibacterium acnes secara in vitro, tetapi tidak lebih superior dibandingkan dengan klindamisin fosfat.
\end{abstract}

Corresponding Author:

Annisa Cahyani

Fakultas Kedokteran, Universitas Lampung, Indonesia

Email: annisacahyani121@gmail.com 


\section{PENDAHULUAN}

Akne vulgaris merupakan penyakit kulit yang berupa peradangan kronis folikel polisebasea yang paling banyak terjadi pada usia remaja hingga dewasa muda (Mahmood, 2017; Morze, et al., 2017). Gambaran klinis berupa komedo, papul, pustul, nodul serta kista. Pustula adalah vesikel yang berisi nanah. Nodul yaitu massa padat yang menonjol $>1 \mathrm{~cm}$ di atas permukaan kulit. Skar atau jaringan parut merupakan komplikasi dari akne vulgaris Peradangan terjadi pada wajah dan leher (99\%), punggung (60\%), dada (15\%), serta bahu dan lengan atas (Djuanda, 2016).

Komedo dibedakan menjadi komedo putih (whiteheads) dan komedo hitam (blackheads), tergantung pada apakah mereka tertutup atau terbuka. Komedo tertutup (white head) terbentuk pada saat penumpukan sebum yang terperangkap didalam unit pilosebasea dan tidak mengandung unsur melanin, di bawah permukaan kulit. Komedo terbuka (blackheads) terbentuk dengan cara yang sama dengan komedo tertutup, hanya saja bagian ruangannya terbuka pada permukaan menjadi teroksidasi dan mengandung unsur melanin sehingga tampak berwarna hitam pada epidermis yang membentuk blackheads (Shrewsbury, 2015; Zeichner, et al., 2017).

Prevalensi akne vulgaris berdasarkan The Global Burden of Diseases pada 187 negara adalah $9,4 \%$ dari populasi dunia dan merupakan penyakit paling umum ke-8 (Tan, et al., 2015). Di Indonesia penderita akne vulgaris pada tahun 2006, 2007, dan 2009 secara berturut-turut yaitu $60 \%, 80 \%$, dan $90 \%$ (Afriyanti, 2015). Adapun penelitian yang dilakukan oleh Mizwar, dkk pada tahun 2009-2011 di RSUP Prof Dr R. D. Kandou Manado, dari 10.003 pasien terdapat 121 (3,59\%) pasien akne vulgaris yang didominasi oleh pasien perempuan sebanyak 75 pasien $(61,9 \%)$, kelompok usia terbanyak 15-24 tahun yaitu 75 pasien $(62,8 \%)$ dengan status pendidikan terbanyak pada pelajar yaitu 73 pasien $(60,3 \%)$ (Mizwar, et al., 2013).

Meskipun bukan merupakan penyakit yang mematikan, namun akne vulgaris memiliki dampak yang besar bagi remaja baik secara fisik maupun psikologik (Afriyanti, 2015). Lebih lanjut akne vulgaris dapat menimbulkan kecemasan, depresi, dan mengurangi rasa percaya diri sehingga akan mengganggu kualitas hidup (Morze, et al., 2017).

Etiologi akne vulgaris masih belum diketahui secara pasti, banyak faktor yang berperan dalam timbulnya akne vulgaris antara lain faktor genetik, ras, faktor endokrin, stres, kosmetik, iklim/suhu/kelembapan, makanan, obat-obatan dan infeksi oleh mikroorganisme. Namun, secara umum patogenesisnya dapat dibagi menjadi 4 yaitu: (1) peningkatan produksi sebum; (2) hiperproliferasi keratinosit; (3) kolonisasi Propionibacterium acnes; (4) proses inflamasi (Djuanda, 2016).

Sebum diproduksi oleh kelenjar sebasea yang merupakan bagian dari unit pilosebasea di kulit. Pertambahan jumlah dan ukuran dari kelenjar sebasea diketahui merupakan akibat dari stimulus hormon androgen yang biasanya akan mulai aktif pada usia remaja. Pertambahan jumlah dan ukuran tersebut menyebabkan sebum yang diproduksi akan lebih banyak dari biasanya (Djuanda, 2016). Sebum mengandung komponen trigliserida yang akan dipecah menjadi asam lemak bebas oleh Propionibacterium acnes (Pappas, et al., 2009). Asam lemak bebas ini dapat meningkatkan kolonisasi dari Propionibacterium acnes, memicu terjadinya inflamasi dan proses komedogenik yang menyebabkan timbulnya akne vulgaris (Djuanda, 2016).

Adanya proliferasi keratinosit pada epitel folikel rambut dan infundibulum akan menyumbat aliran sebum ke permukaan kulit, menyebabkan timbulnya mikrokomedo. Faktorfaktor pencetusnya ialah berkurangnya kadar asam linoleat, stimulasi androgen dan peningkatan IL-1. Penurunan asam linoleat menyebabkan terjadinya defisiensi asam lemak esensial, sehingga memicu hiperkeratosis folikuler dan penurunan fungsi barier epitel yang menimbulkan mikrokomedo (Djuanda, 2016). Mikrokomedo merupakan proses awal pembentukan akne vulgaris dan dapat berkembang menjadi lesi inflamasi atau lesi non inflamasi (Rimadhani, 2015).

Propionibacterium acnes merupakan salah satu flora normal pada kulit yang dapat berperan dalam timbulnya jerawat (MacLeod, et al., 2009). Jumlahnya akan meningkat seiring dengan peningkatan sebum yang merupakan nutrisi baginya. Bila jumlahnya meningkat bakteri ini akan menjadi patogen dan menimbulkan lesi inflamasi pada kulit (Siregar, 2017).

Aktivitas Propionibacterium acnes juga dapat menyebabkan proses inflamasi. Propionibacterium acnes merupakan bakteri Gram positif anaerob aerotoleran yang ditemukan di folikel sebasea. Untuk itu organisme ini paling mudah berkembang pada medium bakteriologik dalam lingkungan anaerob dengan saturasi oksigen hingga $0 \%$. Meskipun dianggap sebagai bakteri anaerob, namun bakteri ini dapat mentolerir saturasi oksigen hingga mencapai 
$100 \%$ dengan tingkat pertumbuhannya yang lebih lambat atau disebut juga dengan aerotoleran (McDowell \& Nagy, 2014). Dinding sel Propionibacterium acnes terdiri dari antigen karbohidrat yang menstimulasi perkembangan antibodi. Antibodi anti-propionibakterium menambah respon inflamasi dengan mengaktivasi komplemen yang menginisiasi proinflamasi. Propionibacterium acnes juga menyebabkan respon inflamasi dengan mengeluarkan respon hipersensitivitas yang lambat dan dengan memproduksi lipase, protease, hialuronidase, dan faktor kemotaktis (Perry \& Lambert, 2006; Afriyanti, 2015).

Propionibacterium acnes dapat dibudidayakan di berbagai media, seperti agar darah, brucella, coklat agar, atau cairan infus otak, di bawah kondisi anaerob hingga mikroaerofilik. Koloni pada agar darah berdiameter 1 sampai $2 \mathrm{~mm}$, biasanya berkilau, melingkar, dan buram tumbuh lebih baik pada $\mathrm{pH}$ antara 6,0 sampai 7,0 dibandingkan dengan lingkungan yang lebih asam atau basa serta dengan suhu yang optimal antara $30^{\circ} \mathrm{C}-37^{\circ} \mathrm{C}$ (Achermann, et al., 2014).

Terdapat beberapa modalitas terapi akne vulgaris mulai dari pengobatan topikal hingga sistemik. Terapi topikal seperti retinoid, benzoil peroksida, asam azaleat dan antibiotik. Terapi sistemik seperti antibiotik oral, terapi hormonal, dan isotretinoin. Terapi tersebut diberikan sesuai dengan derajat keparahan dan respon terhadap terapi (Shrewsbury, 2015). Untuk terapi pada akne vulgaris derajat sedang dan berat adalah pemberian antibiotik. Namun, penggunaan antibiotik dalam jangka panjang dan tidak tepat dapat meningkatkan angka kejadian resistensi obat antibiotic (Webster, 2002).

Di Indonesia Beberapa penelitian melaporkan terdapat jenis tanaman obat yang memiliki khasiat sebagai antimikroba (Kemenkes RI, 2017). Salah satunya ialah tanaman kunyit (Curcuma domestica Val.) (Kemenkes RI, 2007). Kandungan yang terdapat dalam kunyit antara lain adalah minyak atsiri, minyak lemak, senyawa kurkuminoid, dan senyawa turunan lainnya. Kandungan tersebut menjadikan kunyit menjadi tanaman obat yang berefek sebagai antiinflamasi, antivirus, antibakteri, antiprotozoa, antineoplasma, antioksidan, dan antinematosida (Simanjuntak, 2012).

Penelitian yang dilakukan oleh Mohammed (2015) menunjukkan bahwa aktivitas antibakteri kurkumin terhadap bakteri Gram positif yaitu Streptococcus mutans dan Streptococcus pyogenes, masing-masing dengan diameter zona hambat sebesar $9,7 \mathrm{~mm}$ dan 10,2mm (Mohammed, 2015). Penelitian tersebut sesuai dengan teori yang menyatakan bahwa ekstrak kurkumin menghasilkan aktivitas antibakteri terhadap berbagai mikroba dan juga pada bakteri seperti Streptococcus, Staphylococcus, Lactobacillus, Helicobacter pylori. Selain itu, kurkumin juga merupakan penghambat pertumbuhan yang kuat terhadap bakteri Gram positif (Staphilococcus aureus dan Streptococcus mutans), bakteri Gram negatif ( $E$. coli dan Pseudomonas aeruginosa), serta jamur yang bersifat patogen (Candida albicans) (Shahi, et al., 2000).

Pada penelitian yang dilakukan oleh Yuliati, et al. (2016) tentang uji efektivitas antibakteri ekstrak kunyit pada bakteri Bacillus $s p$ (Gram positif) dan Shigella dysentriae (Gram negatif), menunjukkan bahwa zona hambat bakteri Gram positif lebih besar dibandingkan Gram negatif. Hal ini disebabkan karena perbedaan struktur dinding antara bakteri Gram positif dan Gram negatif (Yuliati, 2016). Penelitian Wijayanto (2014) juga menunjukkan bahwa ekstrak etanol rimpang kunyit putih terhadap Staphylococcus aureus (Gram positif) dan Escherichia coli (Gram negatif) mempunyai aktivitas antibakteri lebih besar terhadap pertumbuhan Staphylococcus aureus dibanding Escherichia coli (Wijayanto, 2014). Hidayati, dkk (2002) membuktikan secara in vitro bahwa ekstraksi rimpang kunyit mampu menghambat pertumbuhan bakteri baik Gram positif maupun Gram negatif, seperti $E$. coli, $K$. pneumoniae, $P$. aeruginosa, dan $S$. Aureus.

Secara empiris bahan rimpang kunyit digunakan oleh banyak produk kecantikan di pasaran seperti masker produk Mustika Ratu, Qunyit masker, dan Vcare. Masker tersebut digunakan masyarakat dapat untuk mengatasi akne vulgaris. Namun demikian, sepengetahuan penulis belum diketahui secara pasti mekanisme kerjanya pada terapi akne vulgaris, khususnya mengenai efek antibakteri rimpang kunyit terhadap Propionibacterium acnes. Oleh karena itu, perlu dilakukan penelitian yang bertujuan untuk mengetahui efektivitas antibakteri ekstrak rimpang kunyit terhadap pertumbuhan Propionibacterium acnes sebagai penyebab timbulnya akne vulgaris.

\section{METODE}

Penelitian ini adalah eksperimental laboratorium dengan meneliti efek dari ekstrak etanol 96\% rimpang kunyit (Curcuma domestica Val.) terhadap diameter zona hambat 
Propionibacterium acnes secara in vitro. Metode yang digunakan pada penelitian ini adalah metode Kirby Bauer, yaitu dengan cara meletakkan blank disk (cakram kosong) yang telah diteteskan $50 \mu \mathrm{g}$ ekstrak etanol rimpang kunyit terlebih dahulu dengan konsentrasi yang berbeda-beda dan didiamkan selama 15 menit, kemudian diletakkan pada media Mueller Hinton Agar (MHA) yang sudah diinokulasi Propionibacterium acnes.

Penelitian telah dilakukan di Laboratorium Mikrobiologi, Fakultas Matematika dan Ilmu Pengetahuan Alam (FMIPA) Universitas Lampung dan Laboratorium Mikrobiologi, Fakultas Kedokteran Universitas Lampung. Ekstrasi bahan dilakukan di Laboratorium Kimia Organik, Fakultas Matematika dan Ilmu Pengetahuan Alam (FMIPA) Universitas Lampung. Penelitian dilakukan pada bulan Juli 2018 hingga Januari 2019.

Bakteri Uji yang digunakan dalam penelitian ini adalah bakteri Gram positif $(+)$ batang yaitu Propionibacterium acnes.
Propionibacterium acnes diisolasi pada media agar darah dan diinkubasi pada suhu $37^{\circ} \mathrm{C}$ selama 24 jam. Setelah dilakukan kultur, digunakan media Mueller Hinton Agar (MHA) sebagai media uji diameter zona hambat bakteri.

Bahan penelitian yang digunakan adalah ekstrak etanol 96\% rimpang kunyit (Curcuma domestica Val.) dengan konsentrasi 15\%, 30\%, $50 \%$, $75 \%$ dan $100 \%$, serta kontrol positif dan kontrol negatif sebagai pembanding. Sehingga didapat 7 kelompok perlakuan.

Analisis data pada penelitian ini menggunakan One Way ANOVA dan dilanjutkan dengan uji Post hoc menggunakan Least Significance Difference (LSD) menggunakan software Statistical Product and Service Solutions (SPSS).

Penelitian ini telah melewati kaji etik penelitian dan mendapatkan Ethical Clearance oleh bagian komisi etik dari Fakultas Kedokteran Universitas Lampung dengan Nomor. 104/UN26.18/PP.05.02.00/2019.

\section{HASIL}

Tabel 1. Hasil Pengukuran Diameter Zona Hambat Ekstrak Rimpang Kunyit (Curcuma domestica Val.) terhadap Bakteri Propionibacterium acnes

\begin{tabular}{crrrrrrrr}
\hline \multirow{2}{*}{ Percobaan } & \multicolumn{7}{c}{ Zona Hambat Ektrak Rimpang Kunyit (mm) } & \multirow{2}{*}{ Kontrol (-) } \\
\cline { 3 - 8 } & $\mathbf{1 5 \%}$ & $\mathbf{3 0 \%}$ & $\mathbf{5 0 \%}$ & $\mathbf{7 5 \%}$ & $\mathbf{1 0 0 \%}$ & Kontrol (+) & $p$-value \\
\hline 1 & 0 & 11,2 & 15,5 & 17,4 & 18,7 & 20,7 & 28,2 & \\
2 & 0 & 11,3 & 15,8 & 17,3 & 18,9 & 20,5 & 27,4 & \\
3 & 0 & 11,7 & 16,3 & 18,4 & 19,1 & 21,2 & 28,5 &, 000 \\
4 & 0 & 11,2 & 15 & 17,1 & 18,7 & 20,8 & 28,3 & \\
Total Mean & 0 & 11,35 & 15,65 & 17,575 & 18,85 & 20,8 & 28,1 & \\
\hline
\end{tabular}

Tabel 2. Uji Post Hoc

\begin{tabular}{lrrrrrrr}
\hline \multirow{2}{*}{ Perlakuan } & \multicolumn{8}{c}{ Signifikansi } \\
\cline { 2 - 8 } & Kontrol (+) & Kontrol (-) & $\mathbf{1 5 \%}$ & $\mathbf{3 0 \%}$ & $\mathbf{5 0 \%}$ & $\mathbf{7 5 \%}$ & $\mathbf{1 0 0 \%}$ \\
\hline Kontrol (+) & - &, $000^{*}$ &, $000^{*}$ &, $000^{*}$ &, $000^{*}$ &, $000^{*}$ &, $000^{*}$ \\
Kontrol (-) &, $000^{*}$ & - &, $000^{*}$ &, $000^{*}$ &, $000^{*}$ &, $000^{*}$ &, $000^{*}$ \\
$15 \%$ &, $000^{*}$ &, $000^{*}$ & - &, $000^{*}$ &, $000^{*}$ &, $000^{*}$ &, $000^{*}$ \\
$30 \%$ &, $000^{*}$ &, $000^{*}$ &, $000^{*}$ & - &, $000^{*}$ &, $000^{*}$ &, $000^{*}$ \\
$50 \%$ &, $000^{*}$ &, $000^{*}$ &, $000^{*}$ &, $000^{*}$ & - &, $000^{*}$ &, $000^{*}$ \\
$75 \%$ &, $000^{*}$ &, $000^{*}$ &, $000^{*}$ &, $000^{*}$ &, $000^{*}$ & - &, $000^{*}$ \\
$100 \%$ &, $000^{*}$ &, $000^{*}$ &, $000^{*}$ &, $000^{*}$ &, $000^{*}$ &, $000^{*}$ & - \\
\hline Keterangan: * bermakna $(p$-value $<0,05)$ & \multicolumn{10}{c}{}
\end{tabular}

Keterangan: * bermakna $(p$-value $<0,05)$

Hasil penelitian ini menunjukkan pengukuran diameter zona hambat Propionibacterium acnes pada media Mueller Hinton Agar (MHA) cendrung menguat sesuai dengan peningkatan konsentrasi ekstrak rimpang kunyit, yaitu: pada konsentrasi $15 \%$ sebesar $11,35 \mathrm{~mm}$, konsentrasi $30 \%$ sebesar $15,65 \mathrm{~mm}$, konsentrasi $50 \%$ sebesar $17,575 \mathrm{~mm}$, konsentrasi $75 \%$ sebesar $18,85 \mathrm{~mm}$, dan konsentrasi $100 \%$ sebesar 20,8mm. Pada kelompok kontrol (+) diperoleh rerata diameter zona hambat sebesar $28,1 \mathrm{~mm}$, sedangkan pada kelompok kontrol (-) sebesar 0mm (Tabel 1).

Zona hambat tertinggi diperoleh pada kelompok konsentrasi $100 \%$ dengan rerata diameter zona hambat sebesar 20,8mm, sedangkan diameter zona hambat terkecil diperoleh pada kelompok konsentrasi $15 \%$ yaitu 
sebesar $11,35 \mathrm{~mm}$. Hal ini menunjukkan bahwa semakin besar konsentrasi ekstrak rimpang kunyit maka semakin besar pula zona hambat yang terbentuk.

Dilakukan uji normalitas untuk menilai apakah data berdistribusi normal atau tidak. Uji normalitas menggunakan uji Shapiro-Wilk $(\mathrm{n}<50)$. Hasil uji normalitas menunjukkan p pada kelompok kontrol (+) sebesar 0,235, kelompok konsentrasi $15 \%$ sebesar 0,051, kelompok konsentrasi $30 \%$ sebesar 1, kelompok konsentrasi $50 \%$ sebesar 0,296, kelompok konsentrasi $75 \%$ sebesar 0,272, kelompok konsentrasi $100 \%$ sebesar 0,734. Sehingga dapat disimpulkan bahwa seluruh data terdistribusi normal (nilai $p$ value $>0,05)$.

Uji homogenitas Levene menunjukkan data homogen (nilai $p$-value $=0,099$ ) sehingga memenuhi syarat untuk dilakukan analisis One Way ANOVA. Hasil uji One Way ANOVA menunjukkan nilai $p$-value $=0,000$, sehingga dapat disimpulkan bahwa terdapat pengaruh konsentrasi ekstrak etanol rimpang kunyit (Curcuma domestica Val.) terhadap pertumbuhan Propionibacterium acnes.

Untuk mengetahui signifikansi perbedaan dan rata-rata diameter zona hambat pertumbuhan bakteri pada setiap kelompok dilakukan uji post hoc menggunakan uji Least Significance Difference (LSD). Hasil uji post hoc disajikan dalam tabel 2.

Berdasarkan tabel 2 didapatkan hasil signifikansi $p$-value $<0,05$ untuk setiap kelompok, hal ini berarti terdapat perbedaan signifikan antar setiap kelompok uji serta kelompok kontrol, baik positif maupun negatif. Untuk menentukan daya antibakteri paling efektif maka dilihat beda rerata zona hambat yang dihasilkan oleh kelompok Kontrol (+) dengan masing-masing kelompok uji. Hasil yang diperoleh pada selisih diameter zona hambat kelompok kontrol positif dengan kelompok konsentrasi $15 \%$ adalah $(-16,75)$, pada kelompok konsentrasi $30 \%$ adalah $(-12,45)$, pada kelompok konsentrasi $50 \%$ adalah $(-10,525)$, pada kelompok konsentrasi $75 \%$ adalah $(-9,25)$, dan pada kelompok konsentrasi $100 \%$ adalah (7,3). Kelompok dengan konsentrasi 100\% memiliki efek antibakteri paling efektif karena nilai yang diperoleh mendekati kontrol positif. Meskipun demikian ekstrak rimpang kunyit konsentrasi yang maksimal (100\%) memiliki efek antibakteri Propionibacterium acnes lebih rendah dibandingkan kontrol positif yaitu klindamisin fosfat secara bermakna (selisih rerata diameter zona hambat $7,3 \mathrm{~mm}$, nilai $p$ value $=0,000$ ).

\section{PEMBAHASAN}

Penelitian ini menguji aktivitas antibakteri ekstrak etanol rimpang kunyit (Curcuma domestica Val.) terhadap daya hambat Propionibacterium acnes dengan kontrol positif yaitu klindamisin fosfat $1,2 \%$ topical solution dan kontrol negatif yaitu akuades.

Respon hambat pertumbuhan bakteri dapat diklasifikasikan berdasarkan diameter zona bening, yaitu: $<10 \mathrm{~mm}$ kurang efektif, $10-15 \mathrm{~mm}$ lemah, 16-20mm sedang, dan >20mm kuat (Coyle, 2005). Pada penelitian ini diperoleh hasil diameter zona hambat pada konsentrasi ekstrak rimpang kunyit $15 \%$ dan $30 \%$ sebesar $11,35 \mathrm{~mm}$ dan $15,65 \mathrm{~mm}$, sehingga termasuk dalam respon hambat lemah (10-15mm). Pada konsentrasi ekstrak rimpang kunyit $50 \%$ dan $75 \%$ diameter zona hambat sebesar $17,575 \mathrm{~mm}$ dan $18,85 \mathrm{~mm}$, sehingga termasuk dalam respon hambat sedang. Respon hambat kuat timbul pada konsentrasi ekstrak rimpang kunyit 100\% (diameter zona hambat 20,8mm). Meskipun demikian diameter zona hambat kelompok perlakuan dengan pemberian ekstrak rimpang kunyit konsentrasi paling tinggi (100\%) dibandingkan dengan kontrol positif (klindamisin fosfat), yaitu $20,8 \mathrm{~mm}$ versus $28,1 \mathrm{~mm}$.

Klindamisin fosfat yang digunakan sebagai kontrol positif dalam penelitian ini, bekerja menghambat pertumbuhan atau reproduksi dari bakteri dengan cara memodifikasi atau menghambat sintesis protein melalui mekanisme berikut: (a) Memotong elongasi rantai peptida, (b) Memblok site A pada ribosom, (c) Kesalahan membaca pada kode genetik, (d) Mencegah penempelan rantai oligosakarida pada glikoprotein (Katzung, 2012). Sehingga pada penelitian ini diameter zona hambat terhadap Propionibacterium acnes yang dibentuk oleh ekstrak rimpang kunyit dengan konsentrasi yang paling tinggi sekalipun (100\%), masih jauh lebih rendah dibandingkan dengan klindamisin fosfat $1,2 \%$ topical solution.

Efektivitas antibakteri dalam uji aktivitas antibakteri secara in vitro dipengaruhi oleh beberapa faktor, adapun faktor-faktor tersebut Antara lain ialah: populasi bakteri, konsentrasi antibakteri, komposisi media kultur, nilai $\mathrm{pH}$, waktu inkubasi, temperatur, dan lingkungan sekitar bakteri (Greenwood, 2012). Peneliti berusaha mengontrol faktor-faktor yang dapat dikontrol dengan berbagai cara seperti membuat ekstraksi rimpang kunyit menggunakan pelarut etanol 96\% agar bahan-bahan kimia yang memiliki efek antibakteri pada rimpang kunyit dapat tersari, populasi bakteri dibandingkan 
dengan standar kekeruhan MacFarland 0,5 yang ekuivalen dengan suspensi sel bakteri sebanyak $10^{8}(\mathrm{CFU}) / \mathrm{ml}$, media kultur, temperatur $37^{\circ} \mathrm{C}$, membuat kondisi lingkungan anaerob dengan menggunakan anaerobic jar, serta waktu inkubasi yang dilakukan selama 24 jam. Faktor bahan uji yang tidak dapat dikontrol yaitu keragaman bibit, tempat tumbuh, iklim, kondisi waktu panen, serta proses panen (Greenwood, 2012; Achermann, et al., 2014; McDowell \& Nagy, 2014).

Kandungan senyawa kimia yang terdapat dalam kunyit adalah senyawa fenolik alami seperti curcuminoids, sesquiterpenoid, serta terdapat pula kandungan minyak atsiri. Pada curcuminoids terdapat 3 komponen, yaitu kurkumin (94\%), demethoxycurcumin (6\%), dan bisdemethoxycurcumin $(0,3 \%)$. Sedangkan untuk senyawa sesquiterpenoid terdiri dari arturmerone, curlone, bisacumol, zingiberene, curcumene, germacrone, curcuminol, bsabolene. Curcuminoids memberikan efek warna kuning pada rimpang kunyit, sedangkan turmerone, artumerone dan zingiberene yang terdapat didalam senyawa sesquiterpenoid memberikan aroma yang khas pada kunyit (Kumar, et al.,2017).

Komponen utama dalam rimpang kunyit adalah kurkumin dan minyak atsiri. Berdasarkan hasil penelitian Balai Penelitian Tanaman Rempah dan Obat (Balittro) bahwa kandungan kurkumin rimpang kunyit rata-rata $10,92 \%$ (Sundari, 2016). Penelitian tersebut sesuai dengan Lina (2008) yang menyatakan bahwa ekstrak rimpang kunyit memiliki kadar kurkumin rata-rata $10,72 \%$ (Lina, 2008). Kandungan minyak atsiri dapat diperoleh dari seluruh bagian, mulai dari akar, rimpang, daun hingga bunga. Namun bagian rimpang kunyit mengandung memiliki kandungan minyak atsiri yang lebih tinggi, yaitu 5-6\% (Stanojević, et al., 2015). Sehingga pada penelitian ini digunakan bagian rimpang kunyit.

Banyak penelitian yang membuktikan efek farmakologi lain yang dimiliki kurkumin, seperti antiinflamasi, antioksidan, antikanker, antifertiliti, antiulser, antikoagulan, antimikroba, antihepatotoksik, antirematik dan antidiabetik (Gupta, et al., 2013; Stanojević, Stanojevic, Cvetcovic, et al., 2015; Yadav, et al., 2017). Efek-efek farmakologi pada kunyit tersebut membuatnya menjadi tumbuhan yang memiliki efek menguntungkan pada kesehatan manusia, salah satu diantaranya adalah untuk penyakit hati, kanker, aterosklerosis, masalah haid pada wanita, osteoarthritis, gangguan pencernaan dan infeksi bakteri (Yadav, et al., 2017). Tanaman kunyit dapat dipakai menjadi beberapa bentuk sediaan dalam penggunaan teraupetik. Secara topikal pada kulit, kunyit digunakan untuk menyembuhkan luka, pemfigus, herpes zoster, infeksi parasit pada kulit serta akne vulgaris (Mohammed, 2015).

Penelitian yang dilakukan oleh Warnaini (2013) mengenai uji aktivitas antibakteri ekstrak kunyit konsentrasi 15\%, 30\%, 50\%, 75\% dan $100 \%$ terhadap bakteri Gram positif Bacillus $s p$. Warnaini (2013) melaporkan hasil diameter zona hambat pada konsentrasi $15 \%$ sebesar $11 \mathrm{~mm}$, konsentrasi $30 \%$ sebesar $12,3 \mathrm{~mm}$, konsentrasi $50 \%$ sebesar $13,3 \mathrm{~mm}$, konsentrasi $75 \%$ sebesar $13,7 \mathrm{~mm}$ dan konsentrasi $100 \%$ sebesar $14,7 \mathrm{~mm}$ (Warnaini, 2013). Pangemanan (2016) juga melakukan penelitian yang menguji aktivitas antibakteri ekstrak rimpang kunyit terhadap bakteri Staphylococcus aureus (Gram positif) (Pangemanan, 2016).

Hasil penelitian Pangemanan (2016) menunjukkan bahwa ekstrak rimpang kunyit dengan konsentrasi 5\%, 10\%, 20\%, dan $40 \%$ dapat menghambat pertumbuhan Staphylococcus aureus dengan rerata masing-masing $11 \mathrm{~mm}$, $13,5 \mathrm{~mm}, 14,5 \mathrm{~mm}$ dan $15 \mathrm{~mm}$ (Pangemanan, 2016). Penelitian yang dilakukan oleh Mohammed (2015) mengenai aktivitas antibakteri kurkumin terhadap bakteri Gram positif Streptococcus mutans dan Streptococcus pyogenes, masing masing dengan zona hambat sebesar 9,7mm dan 10,2mm (Mohammed, 2015). Sedangkan uji mengenai efektivitas minyak atsiri pada daun, tangkai bunga, dan daun cengkeh Bali terhadap Propionibacterium acnes dilakukan oleh Lova (2017) dan diperoleh hasil diameter zona hambat sebesar $\geq 18,04 \mathrm{~mm}$ (Lova, 2017). Hasil penelitian Mohammed (2015) dan Lova (2017) tersebut mendukung hasil penelitian ini yang menunjukkan terdapat efek antibakteri Propionibacterium acnes sebagai bakteri Gram positif setelah pemberian ekstrak rimpang kunyit secara in vitro. Namun demikian penelitian ini tidak meneliti lebih lanjut mengenai zat-zat aktif dalam rimpang kunyit yang berperan sebagai antibakteri.

Senyawa kurkumin memiliki efek antibakteri. Mekanisme antibakteri kurkumin yaitu berikatan dengan protein FtsZ dan menghambat perakitan protofilamen sehingga menekan pembentukan cincin $\mathrm{Z}$. Dengan demikian dapat menghambat sitokinesis dan proliferasi bakteri. Ikatan kurkumin pada peptidoglikan bakteri dapat memicu kerusakan pada dinding dan membran sel hingga akhirnya mengalami lisis sel bakteri (Teow, et al., 2016). 
Mekanisme kerja antibakteri minyak atsiri yaitu dengan mengganggu proses pembentukkan membran atau dinding sel bakteri sehingga dinding sel tidak terbentuk atau terbentuk dengan tidak sempurna. Minyak atsiri yang aktif sebagai antibakteri mengandung gugus hidroksil $(-\mathrm{OH})$ dan karbonil. Mekanisme golongan gugus ini dalam menghambat pertumbuhan mikroba adalah dengan cara denaturasi protein. Bobot molekul alkohol berhubungan dengan kerja antimikroba, yaitu apabila bobot alkohol meningkat maka

\section{DAFTAR PUSTAKA}

Achermann, Y; Goldstein, E.J.C; Coenye; Shirtliffa, M.E. (2014). Propionibacterium acne: From commensal to opportunistic biofilm-associated implant pathogen. Clinical Microbiology Reviews. 27(3):419440.

Afriyanti, R.N. (2015). Akne vulgaris pada remaja. Medical Faculty of Lampung University. 4(6):102-109.

Coyle, M.B. (2005). Manual of antimicrobial susceptibility testing. America: American society for microbiology.

Djuanda, A. (2016). Ilmu penyakit kulit dan kelamin. Sri Linuwih SW Menaldi, Ed-7. Jakarta.

Greenwood, D; Barer, M; Slack, R; Irving, W. (2012). Medical microbiology, a guide to microbial infection: pathogenesis, laboratory investigation and control 8 edition. United States: Churchill Livingstone, Elsevier.

Gupta SC, Patchva S, Aggarwal BB. (2013). Therapeutic roles of curcumin: Lessons learned from clinical trials. The AAPS Journal. 15(1):195-218.

Hidayati E, Juli N, Marwani E. (2002). Isolasi enterobacteriaceae patogen dari makanan berbumbu dan tidak berbumbu kunyit (curcuma domestica val.) serta uji pengaruh ekstrak kunyit (curcuma domestica val.) terhadap pertumbuhan bakteri yang diisolasi. Jurnal Matematika Dan Sains. 7(2):43-52.

Katzung, B.G. (2012). Farmakologi dasar dan klinik edisi 10. Jakarta: EGC

Kemenkes RI. (2007). Kebijakan obat tradisional. Jakarta.

Kemenkes RI. (2017). Formularium ramuan obat tradisional. 1-135. Jakarta.

Kumar, A; Singh, A.K; Kaushik, M.S; Mishra, S.K; Raj, P; Singh, P.K; et al. (2017). Interaction of turmeric (curcuma domestica kerja antimikroba akan meningkat pula (Korenblum, et al., 2013).

\section{SIMPULAN}

Terdapat efektivitas antibakteri ekstrak rimpang kunyit terhadap pertumbuhan Propionibacterium acnes secara in vitro, tetapi tidak lebih superior dibandingkan dengan klindamisin fosfat.

val.) with beneficial microbes: A review. Biotech. 7(6):1-8.

Korenblum E, Goulart FRV, Rodrigues IA, Abreu F, Lins U, Alves PB, et al. (2013). Antimicrobial action and anti-corrosion effect against sulfate reducing bacteria by lemongrass (cymbopogon citratus) essential oil and its major component, the citral. AMB Express. 3(44): 1-8.

Lina. (2008). Standarisasi ekstrak rimpang kunyit (curcuma domestica val.). Yogyakarta: Universitas Sanata Dharma.

Lova, I.P.T. (2017). Perbandingan uji aktivitas antibakteri minyak atsiri daun, tangkai bunga, dan bunga cengkeh bali (syzygium aromaticum 1.) terhadap bakteri propionibacterium acne dengan metode disk difusi. [Skripsi]. Bali: Universitas Udayana.

MacLeod DT, Cogen AL, Gallo RL. (2009). Skin microbiology. Encyclopedia of Microbiology. 734-747.

Mahmood, N.F; Shipman, A.R. (2017). The ageold problem of acne. International Journal of Women's Dermatology. 3(2):71-76.

McDowell, A; Nagy, I. (2014). Propionibacteria and disease. Molecular Medical Microbiology: Second Edition.

Mizwar, M., Kapantow, M. G., \& Suling, P. L. (2013). Profil Akne Vulgaris di RSUP Prof. dr. RD Kandou Manado Periode 2009-2011. e-CliniC, 1(2).

http://ejournal.unsrat.ac.id/index.php/eclini c/article/view/3276

Mohammed, N. A., \& Habil, N. Y. (2015). Evaluation of antimicrobial activity of curcumin against two oral bacteria. Autom Control Intell Syst, 3, 18-21.

Morze, J; Przybylowicz, K.E; Danielewicz, A; Obara-Golebiowska, M. (2017). Diet in acne vulgaris: Open or solved problem? Iranian Journal of Public Health. 
46(3):428-430.

Pangemanan, A., \& Budiarso, F. (2016). Uji daya hambat ekstrak rimpang kunyit (Curcuma longa) terhadap pertumbuhan bakteri Staphylococcus aureus dan Pseudomonas sp. eBiomedik, 4(1).

Pappas A, Johnsen S, Liu JC, Eisinger M. (2009). Sebum analysis of individuals with and without acne. Dermato-Endocrinology. l(3):157-161.

Perry AL, Lambert PA. (2006). Propionibacterium acne. Letters in Applied Microbiology. 42(3):185-188.

Rimadhani, M., \& Rahmadewi, R. (2015). Pengaruh Hormon terhadap Akne Vulgaris. Berkala Ilmu Kesehatan Kulit dan Kelamin, 27(3), 218-224.

Shahi SK, Shukla AC, Bajaj AK, Banerjee U, Rimek D, Midgely G et al. (2000). Broad spectrum herbal therapy against superficial fungal infections. Skin Pharmacol Appl Skin Physiol. 13(1):60-64.

Shrewsbury, D. (2015). Acne vulgaris. InnovAiT: Education and Inspiration for General Practice. 8(11):645-672.

Simanjuntak, P. (2012). Studi kimia dan farmakologi tanaman kunyit (Curcuma domestica Val.) sebagai tumbuhan obat serbaguna. Lembaga Ilmu Pengetahuan Indonesia. 17(2):103.

Siregar RS. (2017). Atlas berwarna saripati penyakit kulit ( $3 r d$ ed). Jakarta.

Stanojević, J. S., Stanojević, L. P., Cvetković, D. J., \& Danilović, B. R. (2015). Chemical composition, antioxidant and antimicrobial activity of the turmeric essential oil (Curcuma longa L.). Advanced technologies, 4(2), 19-25.

Sundari, R. (2016). Pemanfaatan dan Efisiensi Kurkumin Kunyit (Curcuma domestica Val) Sebagai Indikator Titrasi Asam
Basa. Teknoin, 22(8).

Tan, J. K., \& Bhate, K. (2015). A global perspective on the epidemiology of acne. British Journal of Dermatology, 172, 3-12.

Teow, S. Y., Liew, K., Ali, S. A., Khoo, A. S. B., \& Peh, S. C. (2016). Antibacterial action of curcumin against Staphylococcus aureus: a brief review. Journal of tropical medicine, 2016.

Warnaini, Cut. (2013). Uji efektivitas ekstrak kunyit sebagai antibakteri terhadap pertumbuhan bakteri bacillus sp. dan shigella dysentriae secara in vitro. Jurnal Makassar, Universitas Hasanuddin.

Webster, G.F. 2002. Clinical review acne vulgaris. BMJ (Clinical Research Ed). 325:475-479.

Wijayanto W. 2014. Uji aktivitas antibakteri ekstrak etanol rimpang kunyit putih (curcuma mangga Val) terhadap staphylococcus aureus ATCC 6538 dan eschercia coli ATCC 11229 secara in vitro. [Skripsi]. Surakarta: Fakultas Kedokteran Universitas Muhammadiyah Surakarta.

Yadav RP, Tarun G, Roshan C, Yadav P. 2017. Versatility of turmeric: A review the golden spice of life. Journal of Pharmacognosy and Phytochemistry JPP. 41(61):41-46.

Yuliati Y. 2016. Uji efektivitas ekstrak kunyit sebagai antibakteri dalam pertumbuhan bacillus sp dan shigella dysentriae secara in vitro. Jurnal Profesi Medika. 10(1):2632.

Zeichner JA, Baldwin HE, Cook-Bolden FE, Eichenfield LF, Fallon-Friedlander S, Rodriguez DA. 2017. Emerging issues in adult female acne. Journal of Clinical and Aesthetic Dermatology. 10(1):37-46. 